\title{
The Preparation of Ribosomal Ribonucleic Acid from Whole Bacteria
}

\author{
By H. K. ROBINSON AND H. E. WADE \\ Microbiological Research Establishment, Porton, nr. Salisbury, Wilts.
}

(Received 14 September 1967)

\begin{abstract}
1. A simple method for the preparation of ribonuclease-free ribosomal RNA is described in which ribonuclease-deficient bacteria are treated with acetone and the RNA is extracted with phenol and purified by precipitating it with potassium acetate. The treatment with acetone appears to render the cell wall permeable to RNA but not to DNA during the extraction with phenol. The method thus avoids the need to disrupt the bacteria and greatly simplifies the subsequent purification. 2. The method has been used successfully with ribonuclease-deficient strains of Escherichia coli, Pseudomonas fluorescens and Staphylococcus epidermidis. The recovered purified RNA accounts for about $70 \%$ of the total ribosomal RNA and shows the normal sedimentation pattern of the $16 \mathrm{~s}$ and $23 \mathrm{~s}$ components in the analytical centrifuge.
\end{abstract}

One of the major problems in the study and detection of RNA depolymerases is the difficulty of obtaining adequate quantities of high-polymer RNA, free from ribonucleases, as substrate. Several moderately priced commercial preparations of RNA that were tested contained a large proportion of acid-soluble nucleotide.

The instability of commercial preparations is largely due to the incomplete removal or inactivation of contaminating ribonucleases. This can be largely overcome by using ribonuclease-deficient strains of bacteria (Wade \& Robinson, 1963, 1966; Cammack \& Wade, 1965) as the source of RNA.

An extraction with phenol provides the most convenient method of isolating ribonucleic acids, but when it is applied to rapidly grown whole bacteria only soluble RNA is released (Brubaker \& McCorquodale, 1963). The treatment of bacteria with sodium dodecyl sulphate to make the ribosomal RNA available (Marmur, 1961; Nomura, Okamoto \& Asano, 1961; Monier, Naono, Hayes, Hayes \& Gros, 1962; Kjeldgaard \& Kurland, 1963) had the disadvantages that the initial product after phenol extraction was heavily contaminated with DNA and the detergent proved difficult to remove from the final preparation (H. K. Robinson \& H. E. Wade, unpublished work).

The method described in the present paper applies the usual process of phenol extraction to acetonetreated ribonuclease-deficient bacteria. In addition to avoiding the need to disrupt the bacteria, the method greatly decreases initial contamination with DNA, which simplifies subsequent purification.

Although high-molecular-weight RNA has been isolated from ribosomes (Barlow, Mathias \&
Williamson, 1963; Cox \& Arnstein, 1963; Cohn, 1964; Ralph \& Bellamy, 1964; Kirby, 1965; Stanley \& Bock, 1965), from bacterial protoplasts (Bogdanova, Gavrilova, Dvorkin, Kisselev \& Spirin, 1962; Littauer \& Eisenberg, 1959) and from disrupted bacteria (Midgley, 1965; Click \& Hackett, 1966 ; Rosset, Julien \& Monier, 1966), these methods are impractical for large-scale preparations. A method of extracting ribosomal RNA from whole cells of Escherichia coli American, type B, depending on conditions of low ionic strength and osmotic pressure has been described by Artman, Fry \& Engelberg (1966), but on a large scale this also presents practical difficulties.

\section{MATERIALS AND ANALYTICAL METHODS}

Conditions for bacterial growth. Escherichia coli M.R.E. 600 was grown by continuous culture on $88 \mathrm{~mm}$-glycerol$15 \mathrm{~mm}-\mathrm{NH}_{3}$-salts medium supplemented with $20 \mathrm{~mm}$ glutamate. The cells were washed once in a solution containing $0.01 \mathrm{M}$-tris and $0.01 \mathrm{M}-\mathrm{MgCl}_{2}, \mathrm{pH} 8$, and stored at $-20^{\circ}$ for up to 18 months. Pseudomonas fluorescens N.C.I.B. 8248 was grown on glucose- $\mathrm{NH}_{3}$-salts medium supplemented with $20 \mathrm{~mm}$-glutamate (Wade \& Robinson, 1965) and stored at $-20^{\circ}$ for 20 months. Staphylococcus epidermidis (laboratory strain) was grown on glucose $(2 \%$, w/v)-yeast extract ( $1.25 \%$ of Oxoid yeast extract L21)salts and stored at $-20^{\circ}$ for 30 months.

Chemicals. Bacteria were extracted with a commercial quality of acetone (Shell Chemical Co. Ltd., London, S.E. 1) and then with a solution containing phenol ( $1 \mathrm{~kg}$.), $m$-cresol (140 ml.), 8-hydroxyquinoline (1g.) and water $(110 \mathrm{ml}$.) (Kirby, 1965) prepared with analytical grades of phenol and 8-hydroxyquinoline (British Drug Houses Ltd., Poole, Dorset). All apparatus was heated at $165^{\circ}$ for more than $1 \mathrm{hr}$. before use to destroy any contaminating ribonucleases.

Bioch. 1968, 106 
Determination of nucleic acids. RNA was determined by an orcinol method (Militzer, 1946) with ribose (Koch-Light Laboratories Ltd., Colnbrook, Bucks.) as a standard and an extended heating period (Markham \& Smith, 1949) of $10 \mathrm{~min}$. (Tables 1 and 2). The equivalent RNA values were derived from the theoretical content of purine-bound ribose (Wade \& Robinson, 1965). When this procedure was applied to the purified RNA, values of about $94 \%$ of those expected were obtained. A comparison of the colour formation with ribose and RNA showed that a period of $20 \mathrm{~min}$. heating was necessary for complete colour development with the latter. This increased period of heating was therefore used for the analysis of the purified preparations in Table 3.

DNA was determined by a sensitive diphenylamine method (Burton, 1956) with high-polymer thymus DNA (British Drug Houses Ltd.) as standard.

Determination of nitrogen, phosphorus and potassium. Total nitrogen was determined by a modification of the Nessler method described by King (1951). Total phosphorus was determined by the method described by King (1951). Potassium was determined with an EEL flame photometer (Evans Electroselenium Ltd., Halstead, Essex) with $\mathrm{KCl}$ in $0.05 \mathrm{M}-\mathrm{H}_{3} \mathrm{PO}_{4}$ as standard.

Determination of protein. The elimination of protein (Scheme 1, Tables 1 and 2) was followed by using a biuret method (Stickland, 1951) with bovine plasma albumin (fraction V; Armour Pharmaceutical Co. Ltd., Eastbourne, Sussex) as standard. The more sensitive Folin method (Lowry, Rosebrough, Farr \& Randall, 1951) was used to determine protein in the final product (Table 3).

Interference by phenol. It was found that concentrations of phenol-m-cresol-8-hydroxyquinoline solution greater than $0.1 \%$ interfered with the determination of nucleic acids and that concentrations greater than $1 \%$ interfered with the determination of protein by the biuret method. When these determinations were applied to fractions withdrawn during the preparation of RNA, it was necessary to extract with 2 vol. of ether to decrease the phenol concentration. A diazotized sulphanilic acid method (Snell \& Snell, 1953) was used to ensure that the concentration of phenols in the final product was too low ( 1 part in 500000 ) to interfere with the determination of protein by the Folin method.

Determination of glycogen. Glycogen was determined as glucose after hydrolysis in $0.6 \mathrm{~N}-\mathrm{HCl}$ for $2 \mathrm{hr}$. at $100^{\circ}$, by using a glucose oxidase-peroxidase method (Huggett \& Nixon, 1957).

Determination of lipopolysaccharide. The lipopolysaccharide from the cell wall of $E$. coli was extracted together with RNA by phenol. 3-Deoxy-2-oxoheptonic acid is known to be a component of this constituent in $E$. coli (Luderitz, Staub \& Westphal, 1966). Its concentration in the preparation of RNA from this bacterium, determined by a modification of the method of Weissbach \& Hurwitz (1954) (D. C. Ellwood, unpublished work), provided a measure of the contamination of the product by lipopolysaccharide. The latter was assumed to have $4 \%$ of 3-deoxy-2-oxoheptonic acid.

Analytical centrifugation. The purity of the final preparation was also assessed by sedimentation analysis in a Spinco model E ultracentrifuge (Beckman Instruments Inc., Belmont, Calif., U.S.A.) with a schlieren optical system as described by Cammack \& Wade (1965). The preparations were dialysed in 1 in.-diam. Visking tubing (Scientific Instrument Centre, London, W.C. 1) that had been boiled for $15 \mathrm{~min}$. in $30 \mathrm{~mm}$-EDTA, washed in water and handled throughout with rubber gloves.

\section{Preliminary small-scale experiments}

Acetone extraction. Experience with acetone-extracted bacteria during a study of bacterial ribonucleases (Wade \& Robinson, 1966) recommended this treatment as a means of killing the bacteria without grossly damaging the ribonucleases or the RNA present. The possibility of extracting RNA from acetone-treated bacteria with phenol was therefore explored.

$E$. coli was treated with $50 \%(\nabla / v)$ acetone for $16 \mathrm{hr}$. at

Table 1. Effect of varying the concentration of acetone and sodium chloride on the extraction of nucleic acids and protein by phenol

$E$. coli (lg. wet wt.) was suspended in $0 \cdot 145 \mathrm{M}-\mathrm{NaCl}$ containing $5 \mathrm{mM}-\mathrm{MgCl}_{2}$ to give $10 \%$ suspensions, which were shaken with acetone to give final concentrations of 50 or $70 \%(v / v)$ acetone. After storage at 16 or $72 \mathrm{hr}$. at $2-4^{\circ}$ the mixtures were centrifuged. The deposits were resuspended in either $3 \mathrm{ml}$. of $0 \cdot 1 \mathrm{~m}-\mathrm{NaCl}$ containing $5 \mathrm{~mm}$-EDTA or $3 \mathrm{ml}$. of $0.7 \mathrm{M}-\mathrm{NaCl}$ containing $5 \mathrm{~mm}$-EDTA and left for $1 \mathrm{hr}$. before being made up to $10 \mathrm{ml}$. with $0.1 \mathrm{M}$ - or $0.7 \mathrm{M}-\mathrm{NaCl}$ respectively. The suspensions were shaken for $30 \mathrm{~min}$. at $20^{\circ}$ with an equal volume of phenol$m$-cresol-8-hydroxyquinoline solution and centrifuged at $3000 \mathrm{~g}$ for $40 \mathrm{~min}$. at $0^{\circ}$. The concentrations of nucleic acids and protein in the aqueous layer were determined after the phenol contamination had been decreased.

Period of storage

$\begin{array}{ccc}\begin{array}{c}\text { in acetone } \\ \text { solution (hr.) }\end{array} & \begin{array}{c}\text { Concn. of acetone } \\ (\%, \nabla / v)\end{array} & \begin{array}{c}\text { Concn. of } \mathrm{NaCl} \\ (\mathrm{M})\end{array} \\ 16 & 50 & 0 \cdot 1 \\ 16 & 50 & 0 \cdot 7 \\ 72 & 50 & 0 \cdot 1 \\ 72 & 50 & 0 \cdot 7 \\ 16 & 70 & 0 \cdot 1 \\ 16 & 70 & 0 \cdot 7 \\ 72 & 70 & 0 \cdot 1 \\ 72 & 70 & 0 \cdot 7\end{array}$

Recovery (\%)

$\begin{array}{ccc}\text { RNA } & \text { DNA } & \text { Protein } \\ 66.0 & 0.22 & 1.05 \\ 80.0 & 5.7 & 1.06 \\ 62.8 & 0 & 1.38 \\ 74.8 & 1.21 & 1.5 \\ 57 \cdot 7 & 0.25 & 1.42 \\ 71 \cdot 6 & 4.5 & 1.72 \\ 51.4 & 0.2 & 1.58 \\ 62.8 & 10.0 & 1.91\end{array}$


Table 2. Effect of temperature and period of shaking on the extraction of nucleic acids and protein by phenol

Acetone-extracted $E$. coli ( $150 \mathrm{~g}$. wet wt.) was suspended in $0.7 \mathrm{M}-\mathrm{NaCl}$ containing $5 \mathrm{~mm}-\mathrm{EDTA}$, made up to $600 \mathrm{ml}$. and left for $1 \mathrm{hr}$. at $0^{\circ}$, before the addition of $900 \mathrm{ml}$. of $0.7 \mathrm{M}-\mathrm{NaCl}$. Then $250 \mathrm{ml}$. volumes were shaken with equal volumes of phenol- $m$-cresol-8-hydroxyquinoline solution on a Kantorowicz shaker for 30 or $120 \mathrm{~min}$. at $20^{\circ}$, $30^{\circ}$ or $40^{\circ}$, before being centrifuged at $2000 \mathrm{~g}$ for $1 \mathrm{hr}$. at $0^{\circ}$. After each aqueous layer had been removed, the interface layer was recovered and centrifuged at $10000 \mathrm{~g}$ for $2 \mathrm{hr}$. at $0^{\circ}$ to obtain a second aqueous layer, which was added to the first. The proportions of total nucleic acids and protein recovered in the aqueous layer were determined after the phenol contamination had been decreased.

$\begin{array}{cccccc}\begin{array}{c}\text { Period of } \\ \text { shaking } \\ \text { (min.) }\end{array} & \text { Temp. } & \begin{array}{c}\text { Vol. of aqueous } \\ \text { layer (ml.) }\end{array} & \text { RNA } & \text { DNA } & \text { Protein } \\ 30 & 20^{\circ} & 173 & 61 \cdot 0 & 7 \cdot 8 & <1 \cdot 0 \\ & 30 & 178 & 67.0 & 19.4 & <1 \cdot 0 \\ & 40 & 176 & 76.3 & 18 \cdot 7 & <1 \cdot 0 \\ 120 & 20 & 177 & 68 \cdot 6 & 30 \cdot 1 & <1 \cdot 0 \\ & 30 & 180 & 65.9 & 34.5 & <1 \cdot 0 \\ & 40 & 182 & 75 \cdot 7 & 36.0 & <1 \cdot 0\end{array}$

$2-4^{\circ}$, suspended $(10 \%$, wet wt./vol.) in $0 \cdot 1 \mathrm{M}-\mathrm{NaCl}$ and extracted with an equal volume of phenol- $m$-cresol8-hydroxyquinoline solution at $20^{\circ}$. About $60 \%$ of the total RNA was found in the aqueous phase together with only $0.22 \%$ of the total DNA and $1.05 \%$ of the total protein. Variations in these conditions were then examined.

Increasing the concentration of acetone from $50 \%$ to $70 \%$ offered no advantages, but increasing the concentration of $\mathrm{NaCl}$ from $0 \cdot 1 \mathrm{M}$ to $0.7 \mathrm{M}$ (K. S. Kirby, personal communication) improved the yield of RNA without seriously increasing the extent of contamination from protein (Table 1). The increased contamination from the DNA (Table l) was not as significant as the values suggest, since the DNA initially present in the bacteria only accounted for about $20 \%$ of the total nucleic acids.

Extending the period of storage in the acetone solution from $16 \mathrm{hr}$. to $72 \mathrm{hr}$. appeared to decrease the yield of RNA, probably owing to the diffusion of soluble RNA from the bacteria (Table 1).

Phenol extraction. The efficiency of deproteinization and RNA extraction was determined with 20,33 and $50 \%$ of the phenol- $m$-cresol-8-hydroxyquinoline solution in the final mixture. The recovery of RNA was similar at all three concentrations, but the economy of using the lower concentration was offset by increases in contamination from protein and DNA of five- and 20 -fold respectively over that at the highest $(50 \%)$ concentration.

Homogenizing the phenol-cell suspension, instead of shaking it, increased the RNA in the aqueous phase by $10-15 \%$, but also increased the concentration of DNA to more than $50 \%$ of the original total (cf. Stansly \& Seese, 1965).

The effect of increasing the temperature and the period of shaking with phenol was also examined. Increasing the temperature from $20^{\circ}$ to $40^{\circ}$ improved the recovery of RNA without greatly increasing the contamination from DNA, but increasing the period of shaking from 0.5 to $2 \mathrm{hr}$. caused a two- to three-fold increase in the contamination from DNA without affecting the RNA recovery (Table 2).

The replacement of $\mathrm{NaCl}$ by inorganic phosphates was also examined, with aqueous solutions of mono-, pyro- and poly-phosphate that were about equimolar with respect to
$\mathrm{Na}^{+}$. No advantages over $\mathrm{NaCl}$ were found and, in fact, practical difficulties were introduced with the higher concentrations of pyrophosphate by the reversal of the layers on centrifuging after shaking with phenol.

Acetate fractionation and ethanol washes. RNA is often precipitated from the aqueous phase with an alcohol (Kirby, 1964) and further purified by washing with cold 3 m-sodium acetate (pH6), which removes soluble RNA, DNA and glycogen (Kirby, 1965). To avoid excessive contamination by inorganic salt in the final product, this order of treatment was reversed (Scheme 1) and the ribosomal RNA was precipitated initially with a high concentration of salt (cf. Aldredge, 1960; Bogdanova et al. 1962; Jones, 1963). Potassium acetate, pH6, was used instead of the sodium salt because of its greater solubility in ethanol. The further advantage of this procedure is the removal of most of the contaminating substances in a single operation. Washing the precipitate in $3 \mathrm{M}$-potassium acetate removes any occluded soluble RNA, DNA and glycogen. Soluble RNA is also soluble in the $50 \%$-ethanol wash.

After the final ethanol wash (Scheme 1), the bulk of the ethanol was removed by suction on a Buchner funnel and the remainder removed under vacuum. Continued sucking in air resulted in a preparation of hard grey lumps that were difficult to dissolve. This was attributed to condensation of water from the atmosphere partly converting the preparation into a gel before it dried. It could be overcome by washing again in $80 \%$ ethanol containing $0.1 \mathrm{mM}$-EDTA and in ethanol, then washing with about $100 \mathrm{ml}$. of acetone and rapidly drying on the Buchner funnel (Table 3, prep. III). Although the preparation obtained in this way was white and finely divided, the treatment appeared to damage the RNA and resulted in diffuse peaks in the analytical centrifuge compared with the air-dried preparation (Fig. 1).

\section{Large-scale preparation}

Washed bacteria ( $1 \mathrm{~kg}$. wet wt.) were suspended in 91 . of $0.145 \mathrm{M}-\mathrm{NaCl}$ containing $5 \mathrm{~mm}-\mathrm{MgCl}_{2}$ at $\mathrm{pH} 6-6.5\left(2-4^{\circ}\right)$ by using a stainless-steel stirrer (Scheme 1). The suspension was shaken vigorously with 101. of acetone and allowed to settle. After 3 days the acetone solution was decanted and the remaining slurry (usually about 61.) was centrifuged at 
Stage

Acetone extraction

Phenol extraction

Acetate fractionation

\section{Ethanol washes}

101 . of a $10 \%$ suspension of bacteria in $0 \cdot 145 \mathrm{M}-\mathrm{NaCl}$ with $5 \mathrm{mM} \cdot \mathrm{MgCl}_{2}$

Shaken with $1 \mathrm{vol}$. of acetone and allowed to settle overnight

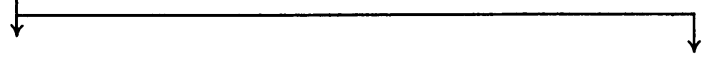

Cell slurry

Clear liquid

(sucked off and discarded)

Centrifuged at 1000 for $30 \mathrm{~min}$.

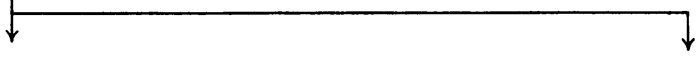

Deposit

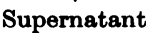

(discarded)

Resuspended in 0.7 M-NaCl with $5 \mathrm{mM}-\mathrm{EDTA}$ and made up to 41.

Kept for $1 \mathrm{hr}$. and 61 . of $0 \cdot 7 \mathrm{M}-\mathrm{NaCl}$ added

Shaken with 1 vol. of phenol-m-cresol-8-hydroxyquinoline soln. at $20^{\circ}$ or $30^{\circ}$ for $30 \mathrm{~min}$.

Centrifuged at $1500 \mathrm{~g}$ for $1 \mathrm{hr}$.

Aqueous layer

Phenol and interface

layers (discarded)

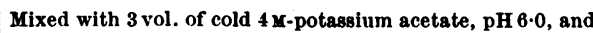

allowed to sediment (liquid decanted and discarded)

Suspension centrifuged at $3000 \mathrm{~g}$ for $30 \mathrm{~min}$.

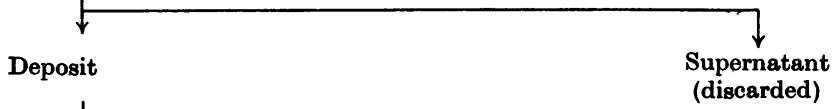

Washed in 11. of $3 \mathrm{M}$-potassium acetate, $\mathrm{pH} 6.0$

Centrifuged at $3000 \mathrm{~g}$ for $20 \mathrm{~min}$.

Deposit

Supernatant

(discarded)

Washed in 11 . of $50 \%$ ethanol

Washed in 11 . of $80 \%$ ethanol with $0.1 \mathrm{mM}$-EDTA

Washed in 11. of ethanol and allowed to sediment (liquid decanted and discarded)

Filtered by suction and deposit washed with $0 \cdot 11$. of ethanol

Dried in evacuated desiccator

Ribosomal RNA preparation

Scheme 1. Isolation of ribosomal RNA from ribonuclease-free bacteria. All stages were carried out at $2-4^{\circ}$ unless otherwise stated. 
$1000 \mathrm{~g}$ for $30 \mathrm{~min}$. at $2-4^{\circ}$. The supernatant was discarded and the deposits were resuspended without vigorous stirring in $0.7 \mathrm{M}-\mathrm{NaCl}$ containing $5 \mathrm{~mm}-\mathrm{EDTA}$ at $2-4^{\circ}$, to give a total volume of 41 .

An effort to decrease the volume to be centrifuged by increasing the concentration of acetone-treated bacteria in the solution of $\mathrm{NaCl}-\mathrm{EDTA}$ from 10 to $25 \%$ (Scheme 1) resulted in a lower recovery of RNA (Table 3, prep. II); this was probably due to the interface layer displacing the phenol as the bottom layer.

After at least $1 \mathrm{hr},, 61$. of $0 \cdot 7 \mathrm{M} \cdot \mathrm{NaCl}$ was added and $250 \mathrm{ml}$. volumes of the suspension were each shaken with an equal volume of phenol-m-cresol-8-hydroxyquinoline solution for $30 \mathrm{~min}$. at 20 or $30^{\circ}$ in a Kilner jar (3lb. size) on the bottom

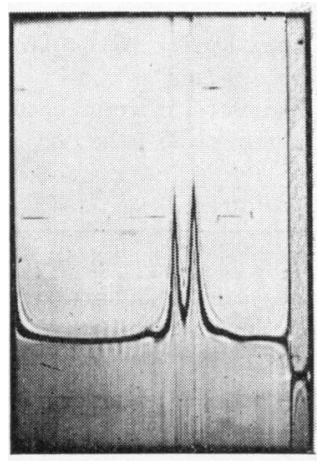

(a)

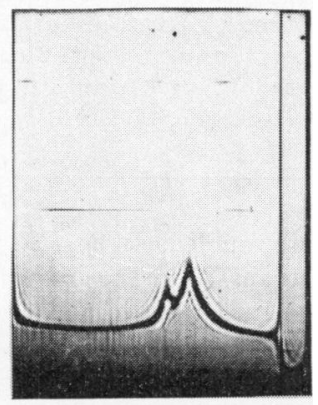

(b)
Fig. 1. Sedimentation diagrams of ribosomal RNA from $E$. coli in $0 \cdot 145 \mathrm{M}-\mathrm{NaCl}$ containing $5 \mathrm{~mm}-\mathrm{MgCl}_{2}$, dialysed against this solution for $16 \mathrm{hr}$. at $2-4^{\circ}$. (a) An air-dried preparation $(8 \cdot 2 \mathrm{mg} . / \mathrm{ml}$.); (b) the same air-dried preparation washed in $80 \%$ ethanol containing $0.1 \mathrm{~mm}$-EDTA and subsequently with acetone $(6.5 \mathrm{mg} . / \mathrm{ml}$.). The patterns were photographed after $26 \mathrm{~min}$. at $47600 \mathrm{rev} \cdot / \mathrm{min}$. at $25^{\circ}$; the phase-plate angle was $60^{\circ}$. shelf of a Kantorowicz (1951) shaker. The product was then centrifuged at $1500 \mathrm{~g}$ for $1 \mathrm{hr}$. at $0^{\circ}$ in a swing-out rotor (type 59560, 6×1000 ml., MSE Mistral model 6L). The upper, turbid, layer was carefully removed by suction, shaken with $3 \mathrm{vol}$. of $4 \mathrm{M}$-potassium acetate (adjusted to $\mathrm{pH} 6$ with conc. $\mathrm{HCl}$ ) at $2-4^{\circ}$ and left for 2 days to allow the precipitated ribosomal RNA to settle.

The solution was decanted and the slurry centrifuged at $3000 \mathrm{~g}$ for $30 \mathrm{~min}$. at $2-4^{\circ}$. The supernatant was discarded and the deposit washed by suspending it in 11 . of cold $3 \mathrm{M}$ potassium acetate, $\mathrm{pH}$, and centrifuging it at $3000 \mathrm{~g}$ for $20 \mathrm{~min}$. The deposit was similarly washed in $50 \%$ ethanol and in $80 \%$ ethanol containing $0.1 \mathrm{~mm}$-EDTA. The deposit was resuspended in 11. of ethanol and left at $2-4^{\circ}$ for the precipitate to settle before the ethanol was decanted. The slurry was filtered through a Whatman no. 50 filter paper on a Buchner funnel and washed by suction with about $100 \mathrm{ml}$. of ethanol.

The ethanol occluded in the product was removed in a desiccator with a two-stage gas-ballast high-vacuum pump (model ED 150; Edwards High Vacuum Ltd., Crawley, Sussex) until the preparation gave a constant weight. The dried product was stored at $-20^{\circ}$.

\section{RESULTS AND DISCUSSION}

Preparations of RNA from $E$. coli that were dissolved in, and dialysed for $16 \mathrm{hr}$. against, 0.145 M-sodium chloride containing 5mM-magnesium chloride showed two major sedimenting components in the analytical centrifuge with approximate $S_{20, \mathrm{w}}^{0}$ values $19 \cdot 6 \mathrm{~s}$ and $26 \cdot 7 \mathrm{~s}$ (Fig. $2 a$ ). A small amount of faster-sedimenting material in the unwashed potassium acetate precipitate (Fig. $2 b$ ), presumably due to the formation of $16 \mathrm{~s}$ and 23s RNA aggregates in the presence of high concentrations of univalent ions (Marcot-Queiroz \& Monier, 1965), largely disappeared during the subsequent washes. When the period of dialysis was

Table 3. Comparison of the yields and final analyses of dried RNA preparations from $1 \mathrm{~kg}$. wet wt. of bacteria

\begin{tabular}{|c|c|c|c|c|c|c|}
\hline \multirow[b]{2}{*}{ Prep.no. $\quad \ldots \quad \ldots$} & \multicolumn{4}{|c|}{ E. coli } & \multirow[b]{2}{*}{ Ps. fluorescens } & \multirow{2}{*}{$\begin{array}{c}\text { Staph. } \\
\text { epidermidi }\end{array}$} \\
\hline & I & II & III & IV & & \\
\hline Generation time (hr.) & $1 \cdot 0$ & $1 \cdot 0$ & $1 \cdot 35$ & 0.94 & $1 \cdot 0$ & 0.75 \\
\hline $\begin{array}{l}\text { Period of storage at }-20^{\circ} \\
\text { of bacteria (months) }\end{array}$ & 8 & 10 & 16 & 1 & 20 & 30 \\
\hline Yield of RNA (g. dry wt.) & $17 \cdot 4$ & $9 \cdot 1$ & $12 \cdot 4$ & $21 \cdot 4$ & $9 \cdot 1$ & $17 \cdot 7$ \\
\hline Temp. of phenol extraction & $20^{\circ}$ & 20 & 20 & 30 & 20 & 20 \\
\hline Ribose (\%) & $22 \cdot 6$ & $21 \cdot 7$ & 21.9 & $22 \cdot 4$ & $22 \cdot 5$ & $20 \cdot 7$ \\
\hline Potassium (\%) & $10 \cdot 7$ & $11 \cdot 3$ & $10 \cdot 0$ & $11 \cdot 3$ & $10 \cdot 2$ & $10 \cdot 0$ \\
\hline Nitrogen $(\%)$ & $14 \cdot 4$ & $14 \cdot 4$ & $14 \cdot 3$ & $14 \cdot 4$ & $13 \cdot 8$ & $14 \cdot 3$ \\
\hline Phosphorus (\%) & $8 \cdot 1$ & $7 \cdot 7$ & 7.9 & $8 \cdot 0$ & $6 \cdot 3$ & $7 \cdot 6$ \\
\hline $\mathrm{N} / \mathrm{P}$ ratio & 1.78 & 1.87 & 1.81 & 1.80 & $2 \cdot 19$ & 1.90 \\
\hline DNA (\%) & $0 \cdot 19$ & 0.09 & 0.09 & $0 \cdot 24$ & 0.47 & 1.02 \\
\hline Protein (\%) & 1.2 & $1 \cdot 1$ & 0.9 & $1 \cdot 2$ & 1.2 & $5 \cdot 0$ \\
\hline Glycogen (\%) & $<0.1$ & $<0.1$ & $<0 \cdot 1$ & $<0.1$ & $<0.1$ & $<0.1$ \\
\hline Lipopolysaccharide (\%) & $<0.25$ & $<0.25$ & $<0.25$ & $<0.25$ & $<0.25$ & - \\
\hline Phenol (p.p.m.) & $<0.1$ & $<0.1$ & $<0 \cdot 1$ & $<0.1$ & $<0.1$ & $0 \cdot 11$ \\
\hline
\end{tabular}




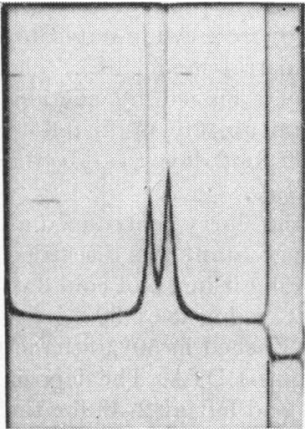

(a)

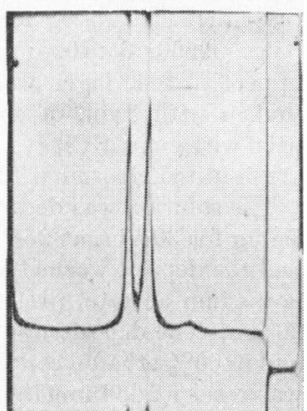

(b)

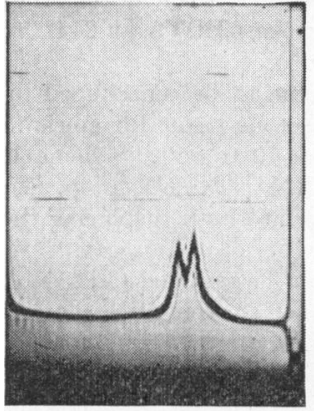

(a)

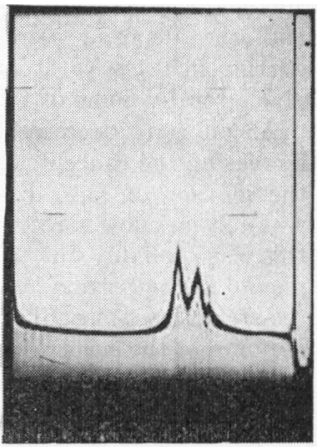

(b)

Fig. 2. Sedimentation diagrams of ribosomal RNA in $0.145 \mathrm{M}-\mathrm{NaCl}$ containing $5 \mathrm{mM}-\mathrm{MgCl}_{2}(\mathrm{pH} 6 \cdot 5)$, isolated from whole cells of $E$. coli. (a) Final preparation dialysed against the solvent for $16 \mathrm{hr}$. at $2-4^{\circ}(8.2 \mathrm{mg} . / \mathrm{ml}$.); (b) unwashed potassium acetate precipitate dialysed for $16 \mathrm{hr}$. at $2-4^{\circ}$ $(8.7 \mathrm{mg} . / \mathrm{ml}$.). The patterns were photographed after $26 \mathrm{~min}$. at $47600 \mathrm{rev} . / \mathrm{min}$. at $25^{\circ}$; the phase-plate angle was $60^{\circ}$.

increased to 15 days, no change in the sedimentation pattern was observed. After storage of the product for 1 year at $-20^{\circ}$ in the dried state, sedimentation diagrams of similarly dialysed solutions showed a difference in the ratio of the two peaks but no other evidence of degradation. More extensive studies on the stability and physical properties of the preparation have been carried out by $K$. A. Cammack \& K. H. Grinstead (unpublished work).

Chemical analyses were carried out on preparations that had been dried to constant weight in vacuo over phosphorus pentoxide at $20^{\circ}$ (Table 3). The yield of ribosomal RNA was naturally dependent on the RNA content of the bacteria used, which reflected the growth rate. The variation between preparations I and II, however, could not be attributed to this and was due most probably to a difference in ambient temperature. The higher yield in preparation IV is now obtained consistently by using bacteria with a generation time of about $1 \mathrm{hr}$. , with the phenol-extraction stage carried out at $30^{\circ}$. In three subsequent preparations, yields of $21.9,22.5$ and $23.1 \mathrm{~g}$. were obtained from $1 \mathrm{~kg}$. wet wt. of bacteria. The chemical analysis of preparations that had been dried to constant weight in vacuo over phosphorus pentoxide at $20^{\circ}$ revealed values close to the theoretical ones (ribose, $22.3 \%$; $\mathrm{K}, 10.2 \% ; \mathrm{N}, 14.5 \% ; \mathrm{P}, 8.2 \% ; \mathrm{N} / \mathrm{P}$ ratio, 1.77 ) for $E$. coli ribosomal RNA with the base composition previously determined (Wade \& Robinson, 1965). The concentrations of DNA and protein were sufficiently low to be ignored in the applications for which the RNA was required.

RNA was also prepared from whole cells of the

Fig. 3. Sedimentation diagrams of ribosomal RNA dialysed against $0.145 \mathrm{M}-\mathrm{NaCl}$ containing $5 \mathrm{mM}-\mathrm{MgCl}_{2}$ (pH6.5) for $16 \mathrm{hr}$. at $2-4^{\circ}$ from (a) Ps. fluorescens $(6.4 \mathrm{mg} . / \mathrm{ml}$.) and (b) Staph. epidermidis $(7 \cdot 0 \mathrm{mg} . / \mathrm{ml}$.). The patterns were photographed after $26 \mathrm{~min}$. at $47600 \mathrm{rev} . / \mathrm{min}$. at $25^{\circ}$; the phaseplate angle was $60^{\circ}$.

ribonuclease-free Ps. fluorescens and a laboratory strain of Staph. epidermidis. In the latter instance, an indistinct initial separation after extraction with phenol necessitated recentrifugation of the interface and aqueous layers. Sedimentation analysis showed the expected two components of ribosomal RNA in both preparations. In the preparation from Staph. epidermidis, however, the faster-sedimenting peak was resolved into two (Fig. 3). The exceptionally high contamination with DNA in both preparations (Table 3) reflected the high concentration in the aqueous phase, due most probably to lysis resulting from the extensive period of storage of the bacteria.

We are grateful to Mr W. J. Brent for skilled technical assistance, to Dr K. A. Cammack and Mr K. H. Grinstead for sedimentation analysis and to Dr D. C. Ellwood for analysis of 3-deoxy-2-oxoheptonic acid.

\section{REFERENCES}

Aldredge, W. G. (1960). Nature, Lond., 187, 323.

Artman, M., Fry, M. \& Engelberg, H. (1966). Biochem. biophys. Res. Commun. 25, 49.

Barlow, J. J., Mathias, A. P. \& Williamson, R. (1963). Biochem. biophys. Res. Commun. 13, 61.

Bogdanova, E. S., Gavrilova, L. P., Dvorkin, G. A., Kisselev, N. A. \& Spirin, A. S. (1962). Biokhimiya, 27, 387.

Brubaker, L. H. \& McCorquodale, D. J. (1963). Biochim. biophys. Acta, 76, 48.

Burton, K. (1956). Biochem. J. 62, 315.

Cammack, K. A. \& Wade, H. E. (1965). Biochem. J. 96, 671.

Click, R. E. \& Hackett, D. P. (1966). Biochim. biophys. Acta, 129, 74.

Cohn, P. (1964). Biochem. J. 90, 31 P.

Cox, R. A. \& Arnstein, H. R. V. (1963). Biochem.J. 89, 574. 
Huggett, A. St G. \& Nixon, D. A. (1957). Biochem. J. 66, $12 P$.

Jones, A. S. (1963). Nature, Lond., 199, 280.

Kantorowicz, I. (1951). J. gen. Microbiol. 5, 276.

King, E. J. (1951). Microanalysis in Medical Biochemistry, 2nd ed., pp. 41, 63. London: J. and A. Churchill.

Kirby, K. S. (1964). Progr. Nucleic Acid Res. molec. Biol. 3, 1.

Kirby, K. S. (1965). Biochem. J. 96, 266.

Kjeldgaard, N. O. \& Kurland, C. G. (1963). J. molec. Biol. 6, 341.

Littauer, U. Z. \& Eisenberg, H. (1959). Biochim. biophys. Acta, 32, 322.

Lowry, O. H., Rosebrough, N. J., Farr, A. L. \& Randall, R. J. (1951). J. biol. Chem. 193, 265.

Luderitz, O., Staub, A. M. \& Westphal, O. (1966). Bact. Rev. 30, 192.

Marcot-Queiroz, J. \& Monier, R. (1965). J. molec. Biol. 14, 490.

Markham, R. \& Smith, J. D. (1949). Parasitology, 39, 330. Marmur, J. (1961). J. molec. Biol. 3, 208.

Midgley, J. E. M. (1965). Biochim. biophys. Acta, 95, 232. Militzer, W. E. (1946). Arch. Biochem. 9, 85.
Monier, R., Naono, S., Hayes, D., Hayes, F. \& Gros, F. (1962). J. molec. Biol. 5, 311.

Nomura, M., Okamoto, K. \& Asano, K. (1961). J. molec. Biol. 4, 376.

Ralph, R. K. \& Bellamy, A. J. (1964). Biochim. biophys. Acta, 87, 9.

Rosset, R., Julien, J. \& Monier, R. (1966). J. molec. Biol. $18,308$.

Snell, F. D. \& Snell, C. T. (1953). Colorimetric Methods of Analysis, 3rd ed., p. 118. New York: D. Van Nostrand Co. Inc.

Stanley, W. M., jun. \& Bock, R. M. (1965). Biochemistry, 4, 1302.

Stansly, P. G. \& Seese, P. G. (1965). Biochim. biophys. Acta, 95, 671.

Stickland, L. H. (1951). J. gen. Microbiol. 5, 698.

Wade, H. E. \& Robinson, H. K. (1963). Nature, Lond., 200, 661.

Wade, H. E. \& Robinson, H. K. (1965). Biochem. J. 96, 753.

Wade, H. E. \& Robinson, H. K. (1966). Biochem. J. 101, 467.

Weissbach, A. \& Hurwitz, J. (1954). J. biol. Chem. 234, 705. 